\title{
音声駆動形身体的色彩変化引込みシステムの開発*
}

\author{
黒田勉*1, 渡辺富夫*2, 山本倫也*3
}

\section{Development of a Speech-Driven Embodied Color-Changed Entrainment System}

\author{
Tsutomu KURODA*4, Tomio WATANABE and Michiya YAMAMOTO \\ ${ }^{* 4}$ Faculty of Education, Kagawa University, \\ 1-1 Saiwaicho, Takamatsu-shi, Kagawa, 760-8522 Japan
}

\begin{abstract}
InterActor is the speech-driven embodied entrainment character for activating human interaction and communication by embodied rhythms between speech and body motions such as nodding in human face-to-face conversation. In this paper, to clarify the visual effect of color change of entrainment on interaction support, a speech-driven entrainment color-changed entrainment system is developed. The system changes color on an object with a visualized response equivalent to nodding in the same timing as InterActor to speech input. By using the system, sensory evaluation by paired comparison demonstrates the effect of color change from the result that the pattern that the color changes from the top of the object is more desirable than the pattern that the whole color changes at a moment.
\end{abstract}

Key Words: Human Interface, Human Interaction, Embodied Interaction, Color Change, Entrainment

\section{1.は じめに}

対面コミュニケーションでは, 対話者の音声とうな ずきや身振りなどの身体動作が相互に引込むことで円 滑にコミュニケーションが行われている。これまでに この身体的引込みに着目して, 対話者の音声と身体動 作の関係を解析し, 音声入力に基づいて人形キャラク タのコミュニケーション動作を自動生成する技術であ る iRT (InterRobot Technology) が確立されてい る(1).この iRT は, 音声駆動形身体引込みキャラクタ InterActor(以下, IA と略する)などの身体的コミュ ニケーションに実装され，その有効性が示されてい る(2)(3).また，人がうなずくタイミングで仮想空間内 での円柱や円盤などプリミティブな形状の $3 \mathrm{D}$ オブジ エクトの動きを表現するインタラクションシステムが 開発され,オブジェクトが「手前に傾きまた元に戻 る」という動きが, 話しやすい引込み反応として有効 であることが示されている(4).

* 原稿受付 2007 年 9 月 21 日.

*1 正員, 香川大学教育学部 (悡760-8522 高松市幸町 1-1).

*2 正員, フェロー, 岡山県立大学情報工学部(画719-1197 総社 市窪木 111)

*3 岡山県立大学情報工学部.

E-mail : kuroda@ed.kagawa-u.ac.jp
一方，色彩には属性間効果における遠近効果として， 同じ大きさの物体を同じ距離から見た場合でも，物体 が前に進出したり，後退したりするように見える効果 が知られており, これらは進出色, 後退色と呼ばれて いる(5)(6). この色彩がもたらす効果を，オブジェクト の色彩変化に応用し, 後退色と進出色を巧く組合わせ ることでオブジェクトが「手前に傾きまた元に戻る」

と同様の動きを表現できると期待される.

このため, 単純な図形の色彩変化により動きと同様 の身体的インタラクションの効果が得られれば, 多様 な場面でインタラクションを支援する新たなシステム が開発できると考えられる、したがって，どのような 色彩変化が引込みを誘発する視覚的効果をもたらすか を検討する,必要がある。

そこで本研究では，キャラクタIAのうなずき反応 をオブジェクトの色彩の変化で置換する音声駆動形身 体的色彩変化引込みシステム (以下, 色彩変化形 IA と 呼ぶ)を開発している。これは, 従来から用いられて いるIA と同じうなずきのタイミングで,オブジェク トの色彩を自由に変化させるもので, 色彩の変化だけ による身体的な引込み効果を表現できるものである。 そして, オブジェクトの基本色彩として進出色の赤と 後退色の青を採用し, 正方形オブジェクトに彩色を施 
して，どのような色彩の時間的変化が「手前に傾きま た元に戻る」ように見せることができる効果をもたら すかを検証している。

\section{2. 色彩変化形 IA システム}

\section{$2 \cdot 1$ 進出色と後退色に基づくオブジェクトの色相} の決定色彩の属性間効果には, 遠近効果 (進出色 と後退色）があり，さまざまな心理作用をもたらすこ とが知られている. 一般的に, 赤, 橙, 黄, 赤紫の順に 進出し, 青, 緑みの青, 青紫が後退するとされてい る(5)(6). 本研究では, オブジェクトの色彩の色相を進 出色のものを赤, 後退色のものを青とした. 色相以外 の色彩に関する要素(明度・彩度)については後述する 值とした。図1は，本研究で使用したオブジェクトの 色彩で, 左側が進出色の赤, 右側が後退色の青である. なお，己れらの色彩提示はカラーディスプレイで行う ため, 加法混色に基づく色彩の変化となる.

\section{$2 \cdot 2$ 色彩変化形 IA システムの動作コンセプト}

色彩変化形 IA システムは, これまでのキャラクタ IA が人の語りかけに対し，人がうなずくタイミングで仮 想空間内でのキャラクタの身振りやうなずき動作を発 生させるのと同じように, 仮想空間内の $3 \mathrm{D}$ オブジェ クトの色彩をうなずきのタイミングで変化させるイン タラクションシステムである.

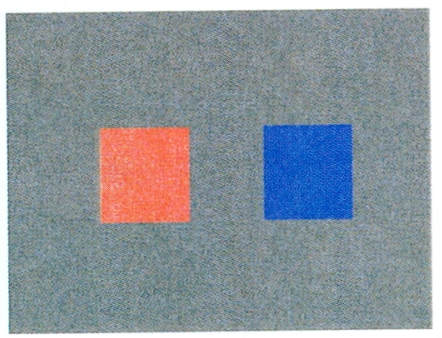

Fig. 1 Advancing color (left) and retreating color (right)

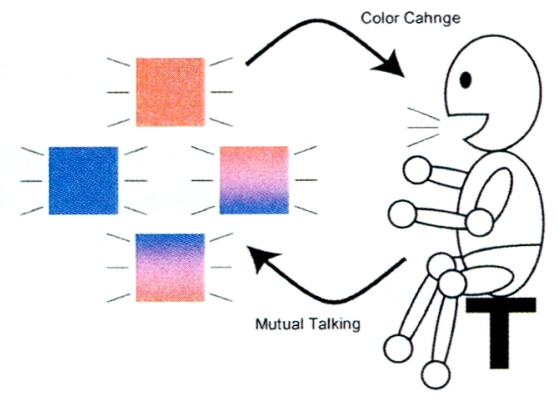

Fig. 2 Concept of the color-changed InterActor system
図 2 は, 本 IA システムのコンセプトを示したもの である.オブジェクトの形状を単純な正方形に設定す ることで, オブジェクトの形状にとらわれない, 純粋 に色彩の変化だけを基にした視覚的効果がもたらす引 込み反応の評価を明確にできる.

\section{$2 \cdot 3$ 色彩変化形 IA システムの構成 このIA} 図 3 に示すように, 話し手の音声をマイクでサウンド カードを搭載する PCに取り込み，その音声を基にデ イスプレイ内の正方形オブジェクトの色彩の変化を制 御するシステムである。システム制御プログラムは Microsoft Visual C++ Ver.6.0により記述し,オブ ジェクトの描画には, Microsoft DirectX 8.0 を用い ている. 画面の解像度は, $1600 \times 1200$ pixel に設定 し, 正方形オブジェクトの大きさは, $335 \times 335$ pixel とした. システムに与えるパラメータを変えること で, 色彩変化の色彩の種類, 時間, タイミングを任意 に設定・変更できるようになっている.

\section{$2 \cdot 4$ 聞き手のうなずき反応 (IA システム) 動作生成} モデル＼cjkstart聞き手のうなずき反応動作を生成する IA システムには, 話し手の発話音声に基づく聞き手のう なずき反応モデル，すなわち話し手の音声の ON$\mathrm{OFF}$ パターンに基づくうなずき反応モデルが導入さ れている。聞き手のうなずき予測モデルを図 4 に示す.

うなずきの予測モデルは, 発話音声の ON-OFF パ ターンから聞き手のうなずき動作を予測する MA (Moving-Average) モデルで，マクロ層とミクロ層か らなる階層モデルである.マクロ層では, 式（1）のユ ニット区間 $(130 \mathrm{~ms}$ 以下の短い音声の $\mathrm{OFF}$ 区間を ON 区間に置換してON 区間を伸ばした呼気段落区 分での ON-OFF 区間）iにおいて，うなずきが存在す るか否かを予測する値 $M u(i)$ を, 式 (2)のユニット 時間率 $R(i)$ (ユニット区間での $\mathrm{ON}$ 区間の占める割 合)の線形結合で求める.

$$
\begin{aligned}
& M u(i)=\sum_{j=1}^{J} a(j) R(i-j)+u(i) \\
& R(i)=\frac{T(i)}{T(i)+S(i)} \cdots \cdots \cdots \cdots \cdots \cdots
\end{aligned}
$$

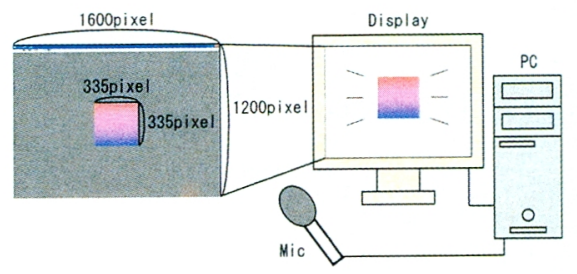

Fig. 3 Configuration of the color-changed InterActor system 


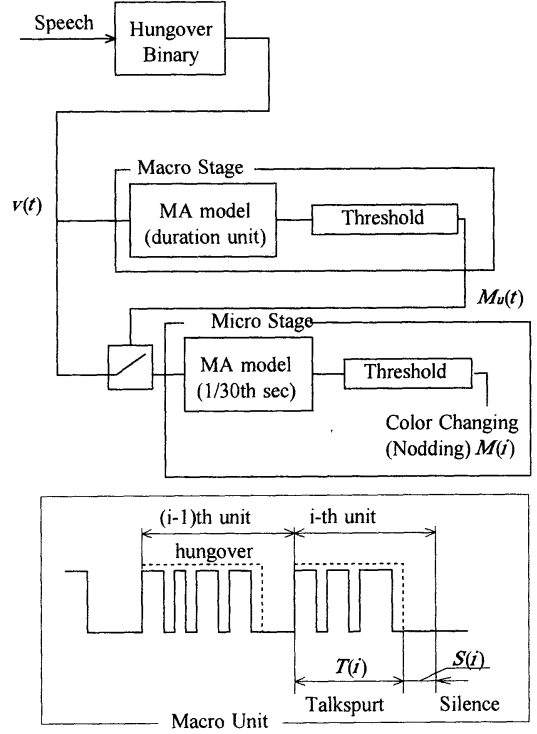

Fig. 4 Listener's interaction model

\section{$J$ : 予測次数 $(6)$}

$a(j)$ : 予測係数

$T(i): i$ 番めユニットでの ON 区間 $S(i): i$ 番めユニットでの OFF 区間 $u(i)$ : 雑音

予測值 $M u(i)$ があらかじめ設定したしきい值を超 えた場合，そのユニット内にうなずきが存在すると判 断し, マクロ層は, 処理をミクロ層に移す.ミク口層 では過去 2 秒間(サンプリングレート $30 \mathrm{~Hz}$ 時には 60 個)の音声の ON-OFFデー夕に基づいて式(3)の MA モデルでうなずきの開始時点 $M(i)$ を推定し, IA をうなずかせる.

$$
M(i)=\sum_{j=1}^{K} b(j) V(i-j)+w(i)
$$

$K$ : 予測次数 $(60)$

$b(j):$ 予測係数

$V(i):$ 音声デー夕

$w(i)$ : 雑音

これらの対面コミュニケーション動作生成モデルは 対面コミュニケーションでの音声と身体動作の関係を 分析した結果に基づくものであり, 従来形のキャラク 夕に扔ける有効性はすでに確認されている(1)(3). 本 IA システムでは, 生成される対面コミュニケーショ ン動作のうち，うなずき生成のみを用い，色彩変化に 対応させている.

$2 \cdot 5$ 色空間 本 IA システムでは, システム上に 抢ける色彩の提示を行うために RGB 色空間を，色彩
の変化を示すための軌跡を表現するために HSV 色空 間を使用している(7) (9).

RBG 色空間とは光の三原色である赤 (Red), 緑 (Green), 青(Blue)の 3 種類の基準化された数值で色 を表現する方式であり，主としてコンピュータ上でオ ブジェクトの色彩を表示するときに用いられている. 本研究では, RGB 各 8 ビット・256 階調を用い, 1677 万色表現可能な RBG 色空間としている.

HSV 色空間は, 色彩の種類を示す色相 $H(\mathrm{Hue})$, 濃度を示す彩度 $S$ (Saturation), 明るさを示す明度 $V$ (Value)の 3 種類の数值で色を表現する方式で, 直 感的にわかりやすい表示となっているので, $\mathrm{CG}$ 等の 色彩の数值表現で広く用いられている.色相は基準と なる赤 $(\mathrm{R})$ を $H=0$ とし, 緑 $(\mathrm{G})$ を $H=120$, 青 $(\mathrm{B})$ を $H=240$ とした角度で表示され，彩度 $S$ を半径とする 極座標平面 ( $H S$ 平面) を構成する. 明度 $V$ は $H S$ 平 面の高さを示す。したがって, $H$ の範囲は $0 \leqq H<$ $360, S$ および $V$ の範囲は $0 \leqq\{S, V\} \leqq 100$ である. また, HSV 色空間と RGB 色空間は, 簡単な変換式で 相互変換が可能である。

\section{$2 \cdot 6$ 色彩変化形 IA の反応パターン}

$2 \cdot 6 \cdot 1$ オブジェクトの基本色 手前に傾き元に 戻る動作が最も高く評価されることが示されているこ とから, 色彩の変化を用いてうなずき反応と同様な視 覚効果を得るためには，オブジェクトの上部が近づき， 下部が遠ざかる視覚効果をもたらせることができれば よいと考えられる.したがって, オブジェクトの色彩 を後退色とし, 上部から進出色に変化していくパター ンがこの視覚反応に最も合致するものである．対比す る色彩の変化として, オブジェクトの色彩を進出色と し, 上部から後退色に変化していくパターン, 並びに オブジェクト全体の色彩が変化するパターンを設定し た。したがって, 本研究で提示する色彩変化パターン は 4 種類となる.

オブジェクトの色彩は, 進出色の赤 $(H=0)$ と光の 三原色であり，かつ後退色でもある青 $(H=240)$ とし， $2 \cdot 6 \cdot 2$ 項以降に示す要領で, 音声に対して逐次色彩を 変化させていくようにした。

$2 \cdot 6 \cdot 2$ オブジェクトの色彩変化の $H S$ 平面上での 軌跡 明度の変化が伴うと, 色彩の見元方のうち 「膨張」「収縮」の効果が発生してくる。これでは, 「色彩そのもののもつ効果」を検証できないため, 明 度の変化を行わないものとした。したがって本 IA シ ステムの色彩変化は, HSV 色空間のうち同一平面上 での変化を示す $H S$ 平面上での変化を示すことにな る.また, 色相の変化量 $(\Delta H)$ は, オブジェクトの基 
本色相である赤 $(\mathrm{R}, H=0=360)$ と青 $(\mathrm{B}, H=240)$ の色 相差の $120(\Delta H=120)$ とした. そして, 明度 $V$ の值 は 100 (最大値)で一定とした。

図 5 は, オブジェクトの色相・彩度, 並びに変化の 軌跡をHS 平面上において示したものである.オブ ジェクトの基本色である赤と青のそれぞれの彩度 $(S)$ は $S=45$ とした. これは, 予備実験時に, 彩度 $S$ が 50 以上のオブジェクトでは, オブジェクトの色彩の変 化時のちらつきが大きく, 特に彩度 $S$ が 80 を超える 場合では「ぎらつく変化」となってしまい, 目の疲労 も著しくなり, 対話実験に支障が出る可能性があった ためである、また, 変化の中間色の彩度を基本色より さらに下げたことも, この理由による.

色彩の変化の軌跡は, $S=45$ の円周と $H=0, S=$ 45 と $H=240, S=45$ を結んだ直線の中心を通るよう にした。したがって, 本システムで変化する色彩は, 純粋に同一彩度上で色相が変化するのではなく, 変化 の途中で彩度が低下(色彩の濃度が薄くなる)する総合 的な色彩変化である.

$2 \cdot 6 \cdot 3$ 実験で提示する色彩変化形 IA 提示する 色彩変化形 IA は 2・6・1 項で示した 4 種類の色彩の組 合せでそれぞれパターン $\mathrm{a} \sim \mathrm{d}$ と呼び, 以下のように 設定した. 図 6 に, それぞれのパターンでの色彩変化 を示す。

まず, パターン a の反応は, オブジェクトを縦方向 に 120 分割して上のオブジェクトから順に赤 $(H=0)$ から青 $(H=240)$ まで $2 \cdot 6 \cdot 2$ 項に示した軌跡(以下, 軌 跡と表す)に沿って変化させ, 最上部のオブジェクト の色相が青 $(H=240)$ となった時点で元に戻らせてい る。次に, パターンbの反応は, オブジェクト全体を 赤 $(H=0)$ から青 $(H=240)$ まで軌跡に沿って変化さ せ, 元に戻らせている.さらに, パターンcの反応は パターン a とは色相が逆になった色彩変化で, パター ン a と同様, オブジェクトを縦方向に 120 分割して上

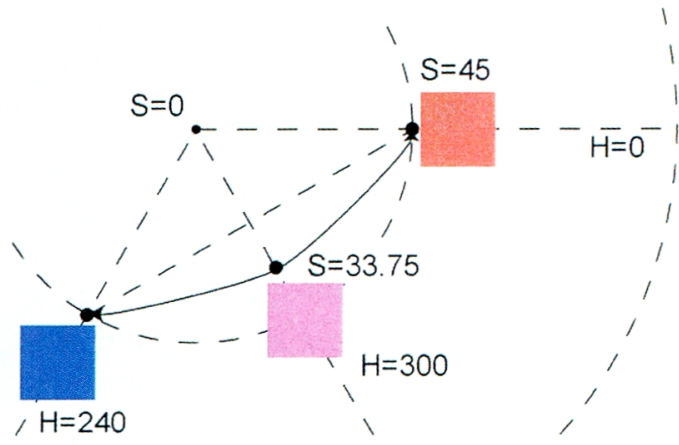

Fig. 5 Outline of color change on HS-plane
のオブジェクトから順に青 $(H=240)$ から赤 $(H=0)$ ま で軌跡に沿って変化させ, 最上部のオブジェクトの色 相が赤 $(H=0)$ となった時点で元に戻らせている. 最 後に, パターン d の反応は, オブジェクト全体を青 $(H=240)$ から赤 $(H=0)$ まで軌跡に沿って変化させ, 元に戻らせており, パターン b とは色相が逆になった 変化となる。

すべての色彩変化は毎秒 30 フレームで提示し, 24 フレーム $(0.8$ 秒 $)$ で反応を完了するように設定した.

\section{3. 色彩变化反応の合成的解析}

色彩変化形 InterActor を用いてどのような色変化

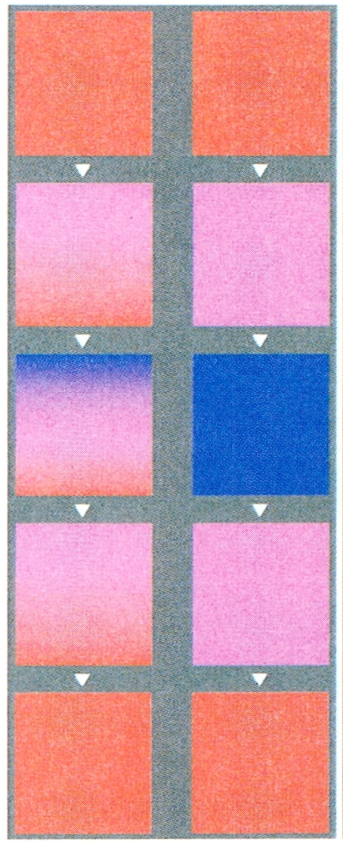

Pattern a Pattern b

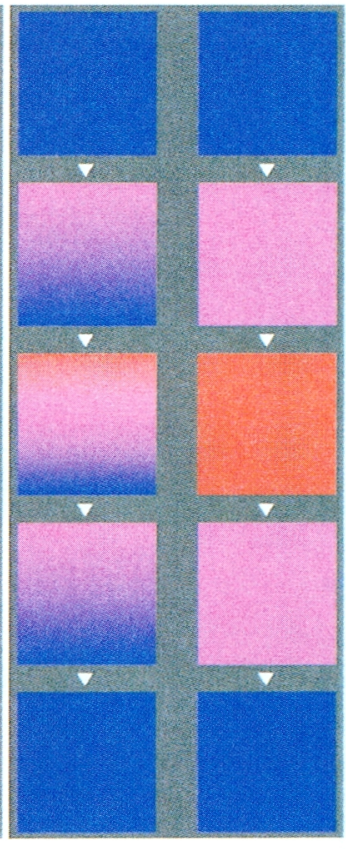

Pattern c Pattern d
Fig. 6 Color-changing patterns in the experiment

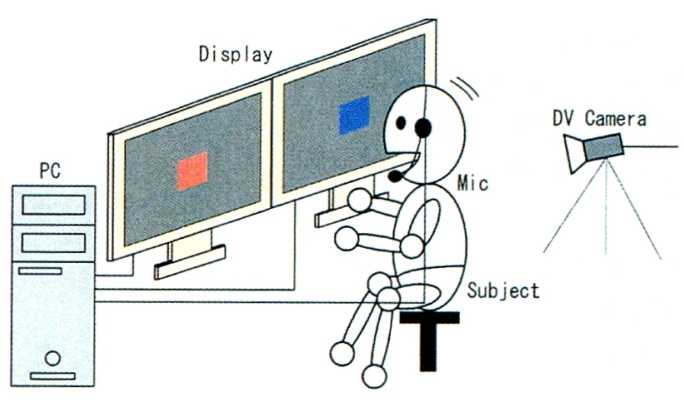

Fig. 7 Experimental setup 
反応が話しやすいかについて官能評価実験を行った. 実験では二つのディスプレイにそれぞれ別の色彩変化 をするオブジェクトを同時に提示し, 反応を一対比較 させた. 反応パターンは $2 \cdot 6 \cdot 3$ 項に示した 4 パターン である.被験者は, 18 歳から 22 歳までの 40 人である.

$3 \cdot 1$ 実験装置実験の構成図を図 7 に示す。被 験者の音声をマイク(マイク屋製 1 スピーカーヘッド セットy 2-02)で PCに取り込み，オブジェクトの反 応を制御している. 音声データは $22.5 \mathrm{kHz}, 16 \mathrm{bit}$ でサンプリングしている.実験ではグラフィックカー ド (nvidia Quadro 3200)を搭載したワークステーショ ン(日本ヒューレット・パッカード製 hp work station xw 4200, CPU : Pentium $43.60 \mathrm{GHz}, \mathrm{RAM}$ : $512 \mathrm{MB})$ を用い, オブジェクトを表示するディスプレ イには20.1 形 LCD(SHARP 製 LL-T 2020, $1600 \times$ 1200 画素)を使用した。オブジェクトの反応を同期さ せるために，2台のディスプレイを用いてグラフィッ クカードのデュアルディスプレイモードを使用した。 被験者とディスプレイの距離は $70 \mathrm{~cm}$ とし, ディスプ レイが同一平面となるように配置した。

$3 \cdot 2$ 話しやすさの評価実験うなずきの引込み 反応は，対話の流れを調整する役割を果たし，身体的 インタラクション支援の観点からは, 話しやすいかど うかが重要であるので(4), 本システムの色彩引込みに よる有効性を話しやすさを評価指標として官能評価し た. 被験者に, 左右のディスプレイに描画される二つ のオブジェクトに語りかけてもらい，どちらの色相変 化の反応が「話しやすい」かを二者択一で一対比較さ せた.この一対比較を $2 \cdot 6 \cdot 3$ 項に示した 4 パターンか らランダムに同一でない 2 パターンを順次選び出し, 6 組のパターンを提示した．表示位置による見え方の 違いをなくすために，描画するディスプレイを左右入 れ替えた合計 12 組のパターンを提示し, アンケート による評価を行わせた. 入力音声は, 日常会話の対話 とした。図 8 に実験風景を示す。

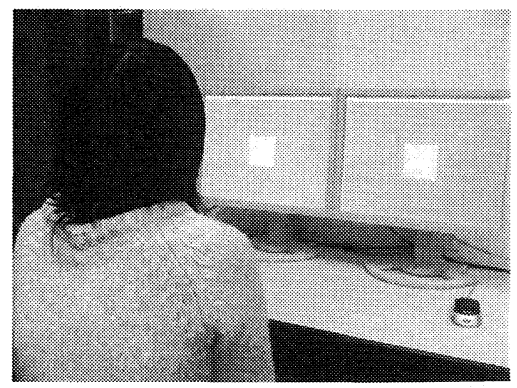

Fig. 8 Scene of experiment
3•3 Bradley-Terry モデルによる話しやすさの評 価一対比較による官能検查結果を表 1 に示す。表 中の数字は, 各パターンの話しやすさの勝ち数を示し ている.この検査結果を定量的に評価するために, 以 下に示す Bradley-Terry モデルを想定した(10).この モデルは, 強さを表す尺度を $\pi$ とし $i$ 番めの要素の強 さを $\pi_{i}$ とするとき，この $\pi_{i}$ の值が大きいほど他の要 素に比べて強いと判断することができる.ここで要素 の数が $m$ 個とすると, 各要素に対応して $m$ 個の量 $\pi_{1}, \pi_{2}, \cdots, \pi_{m}$ が存在して,すべての $i, j の$ 組合せに 対し, 要素 $i$ が $j$ に勝つ確率が, 式 (4)で表される.

$$
\begin{aligned}
& P_{i j}=\frac{\pi_{i}}{\pi_{i}+\pi_{j}} \cdots \cdots \ldots . . . . . \\
& \sum_{i} \pi_{i}=\text { const. }(=100) \\
& \pi_{i}: i \text { の強さの量 } \\
& P_{i j}: i \text { が } j \text { に勝つ確率 }
\end{aligned}
$$

本研究において， $\pi_{i}$ はオブジェクトの色彩が変化した ときの話しやすさを表し，このモデルを想定することに より，一対比較の結果に基づく話しやすさを一義的に定 めることができる. $\pi$ の強さの計算結果を図 9 に示す.

Bradley-Terry モデルが成り立つ，すなわち確率か ら強さというものが一義的に定められるためには， 「順位づけをしたいすべての要素の間に, 強さの線形 順序が成り立たなければならない」という前提条件が 必要で, 本モデルでの整合性を検討する必要がある.

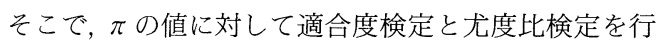
った結果，モデルが棄却されず，強さ $\pi$ の妥当性が保 証された。

以上の結果より, パターン c, パターン $\mathrm{a}$, パターン $\mathrm{b}$, パターン d の順序で, 話しやすいと評価された。 したがって, 反応のタイミングは同じであっても，色

Table 1 Results of the experiment

\begin{tabular}{|c||c|c|c|c||c|}
\hline & a & b & c & d & Total \\
\hline \hline Pattern a & & 48 & 37 & 47 & 132 \\
\hline Pattern b & 32 & & 31 & 41 & 104 \\
\hline Pattern c & 43 & 49 & & 57 & 149 \\
\hline Pattern d & 33 & 39 & 23 & & 95 \\
\hline
\end{tabular}

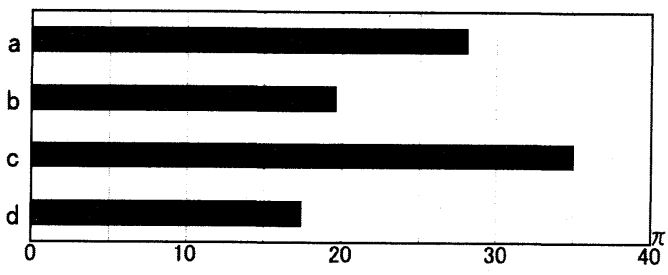

Fig. $9 \pi$ based on the Bradley-Terry model 
彩変化のパターンが異なることでインタラクション効 果が変化することが明らかになった。

$3 \cdot 4$ 考察 まず, オブジェクトの逐次的な色彩 変化の視覚効果が, 話しやすさへの影響がより高いと 考えられる.これは, オブジェクト全体の色相を変え るパターン $\mathrm{b}, \mathrm{d}$ と比較して, 色相を上部から下部に 向けて逐次変化させるパターン $\mathrm{a}, \mathrm{c}$ の評価が高かっ たことにより，オブジェクト全体の色相の変化より, オブジェクトの色相が逐次変化してまた元の色に戻る 色相の変化が高く評価されたためである. 次に，色彩 の変化方向は話しやすさに影響を及ぼすことを示して いると考えられる.これは, オブジェクトの基本色が赤 のパターン a り, オブジェクトの基本色が青のパター ン cの評価值が高かったためである. パターンcの色彩 の変化は, 進出色である赤が上部から順次見えてくる ことで, オブジェクトの上部が前に出てきているよう に見え，正方形のオブジェクトが，「手前に傾きまた元 に戻る動作をしている」ように見えることを示している。

以上のことから, 色彩変化形 IA では, うなずきの タイミングで逐次的にオブジェクトの色彩を変化させ 「手前に傾きまた元に戻る動作をしている」ように見 せることで, 身体的かかわりを有するオブジェクトの 変化を提示できることが示された.

\section{4. 終わりに}

うなずきのタイミングで身体的な引込み効果をオブ ジェクトの色彩変化のみで表現できる音声駆動形身体 的色彩変化引込みシステムを開発した。これは, オブ ジェクトの基本色彩として進出色の赤と後退色の青を 採用し, 正方形オブジェクトに彩色を施して,「手前に 傾きまた元に戻る」ように見せることができる効果を もたらすものである．本システムを用いて官能評価実 験を行った結果, 後退色のオブジェクトの上部から進 出色に変化するパターンが高く評価され, 次いで進出 色のオブジェクトの上部から後退色に変化するパター ンであった. そして, オブジェクト全体の色彩が変化 するパターンの評価は低いことが示された.このこと から，音声に対する聞き手の反応として，人のうなず き動作を連想させる,「手前に傾き元に戻る」視覚効 果の有効性が明らかになった．この視覚効果は $3 \mathrm{D}$ オ ブジェクトの形状にかかわらず, 形状変化を伴わない 聞き手の反応として身体的コミュニケーションシステ ムに広く応用できると考えられる。

今後の課題として, 今回行った色相変化のパターン との基本色として, 光の三原色の一つである緑を用い た赤と緑の変化, 緑と青の変化についても検討する必
要がある．緑は, 進出色・後退色いずれにも当てはめ られないため，青と赤の組合せと異なった見え方にな ると考えられる.また，色相の変化量も $\Delta H=120$ と 大きなものであるため, $\Delta H=60$ 程度とした，より近 い色相の変化での身体リズムの引込み現象の確認・検 討が必要である.

また同時に, ビデオ画像へのテキスト文付加時での テキスト文字の色彩変化など色彩変化形 IA の特徵を 生かした応用分野を創出していく予定である.

本研究の一部は, 文部科学省科学研究費補助金萌芽 研究 15650180870 並びに, 独立行政法人科学技術振興 機構 (JST) 戦略的創造研究推進事業 (CREST) 研究領 域「デジタルメディア作品の制作を支援する基盤技 術」における「人を引き込む身体性メディア場の生 成・制御技術」プロジェクトの助成による。

\section{文献}

(1) Watanabe, T., Okubo, M. and Danbara, R., InterActor : Speech-Driven Embodied Interactive Actor, International Journal of Human-Computer Interaction, Vol. 17, No. 1 (2004), pp. 43-60.

(2) Watanabe, T., E-COSMIC: Embodied Communication System for Mind Connection, Proc. of the 13th IEEE International Workshop on Robot-Human Interactive Communication (RO-MAN 2004), (2004-9), pp. 1-6.

(3) Danbara, R., Watanabe, T. and Okubo, M., Effects of Speech-driven Embodied Entrainment Character "InterActor" on Talker's Speech, Transactions of the Japan Society of Mechanical Engineers, Series C, Vol. 71, No. 712 (2005), pp. 3486-3493.

(4) Yoshida, M., Watanabe, T. and Yamamoto, M., Development of a Speech-Driven Embodied Entrainment System with 3 DCG Objects, The Transactions of Human Interface Society, Vol. 9, No. 3 (2007), pp. 8796.

(5) The Color Science Association of Japan ed., Handbook of Color Science, 2nd ed., (1998), pp. 375-376, University of Tokyo Press.

(6) Takagi, M. and Shimoda, H. eds., Handbook of Image Analysis [Revised Edition], (2004), pp. 457-463, University of Tokyo Press.

( 7 ) Kuroda, T. and Watanabe, T., Analysis and Synthesis of Facial Color Using Color Image Processing, Transactions of the Japan Society of Mechanical Engineers, Series C, Vol. 63, No. 608 (1997), pp. 1255-1260.

(8) Kuroda, T. and Watanabe, T., Facial Color Image Analysis and Synthesis for the Virtual Face Image in Emotional Change, Transactions of the Japan Society of Mechanical Engineers, Series C, Vol.65, No. 638 (1999), pp. 4114-4120.

(9) Harrington, S. and Koriyama, A., COMPUTER GRAPHICS-A Programing Approach-[II], 2nd ed., (1989), pp. 484-499, McGrow-Hill.

(10) Analysis of Scientific Data (Basic Statistics 3) Statistics Section, Depertment of Social Sciences, College of Arts and Sciences, University of Tokyo, (1992), pp. 166-170, University of Tokyo Press. 